\title{
Why should anyone care about extinctions?
}

\section{Kenneth Mellanby}

Extinction: The Causes and Consequences of the Disappearance of Species. By Paul and Anne Ehrlich. Pp.305. ISBN 0-394-51312-6. (Random House, New York: 1981.)\$15.95. To be published in the UK in April 1982 by Gollancz.

PROFESSOR Paul Ehrlich is a distinguished entomologist, known for his meticulous studies of butterfly populations. He is also known to a wider public as a leading prophet of doom. Fortunately, when he has been rash enough to fix dates for particular disasters, his prophecies have seldom been fulfilled. Thus in an article published in 1969 he forecast that "there had been the final gasp of the whaling industry in $1973 \ldots$ by 1977 the annual yield of fish from the sea was down to 30 million tons . . . by September 1979, all important life in the sea was extinct [and] Japan and China were faced with almost instant starvation ....". Now marine pollution has had harmful effects, but the oceans are probably as productive today as they were 12 years ago.

Yet sensible men must agree that our species is increasing in number too rapidly, and that the world's resources are being used too wastefully. The horrors foretold by Ehrlich and others are still possible unless populations are controlled and resources safeguarded. However, I believe that exaggerated statements of imminent disaster are generally counter-productive. Instead of acting as warnings, they actually induce the complacency they are trying to prevent. They have contributed to what another author has recently described as "a waning of public enthusiasm in America for environmental issues".

In this latest book, Paul and Anne Ehrlich are still concerned with problems of global survival, but they restrict their attention to the way in which man is eliminating many species of plants and animals which coexist with him on the surface of the Earth. They avoid any more rash forecasts of dates when extinctions will occur, and even suggest that we may have 15 or so years to put our house - our globe - in order. They do, however, fear that the rate at which species disappear will accelerate, particularly in the tropics where vast areas of forest are being felled. Few scientists will disagree with their general forecasts of the extinction of species, though their views on the effects on life on Earth are less generally acceptable.

Extinctions have always taken place. There is little doubt that the vast majority of species which have evolved during the 3,000 million or so years during which life has existed on Earth are extinct. Some have suggested that we should therefore not worry about further extinctions; they believe that new organisms suited to

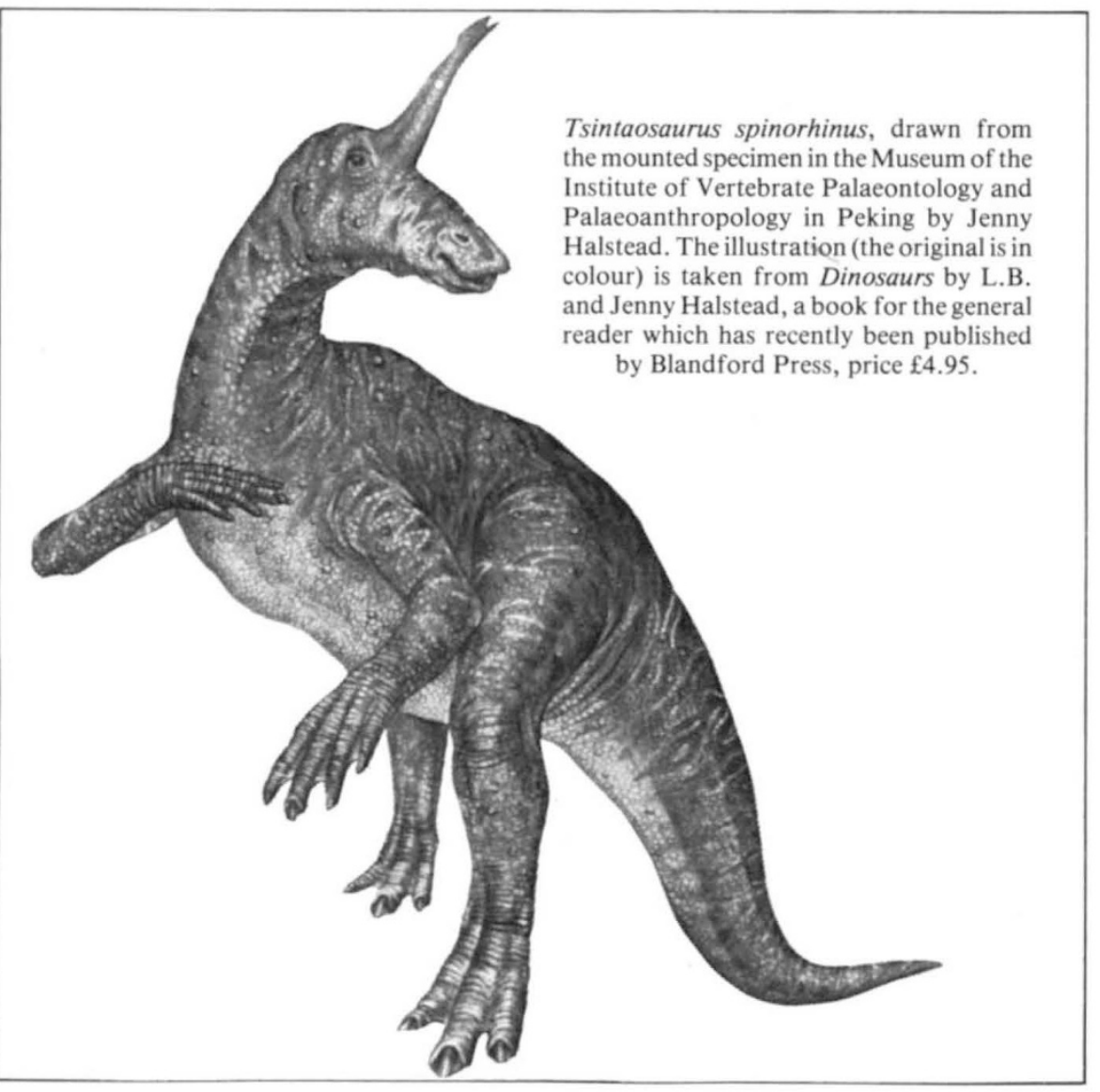

today's world will evolve to fill the vacant niches. Unfortunately this is unlikely, because man produces such sudden changes that there is no time for new forms to evolve. Thus the Ehrlichs point out that much as we may regret, from an aesthetic and scientific standpoint, the passing of the dinosaurs, their place has been taken by mammals and birds. If today we kill off the remaining elephants and rhinoceroses, the world's fauna will be depleted before any replacements have appeared.

As a conservationist I regret all extinctions, whether locally as of the large blue butterfly in Britain, or globally, as of the dodo, the great auk or the passenger pigeon. I wish I could help to reverse the trend. But we must accept that the majority of people do not care, and in fact are doing much to accelerate the process. How can we convince them of the error of their ways?

The Ehrlichs give four reasons. First, compassion - all species on "Spaceship Earth" have an equal right to exist. Second, aesthetic and spiritual - wildlife contributes to the beauty and interest of the world. Third, economic - many organisms, their potential as yet unrecognized, may be exploited as food or other resources, or may provide essential genetic material for crops, livestock or drugs. Fourth, and in the Ehrlichs' view most importantly, by eliminating other species man is endangering the whole global life-support system, and so rendering our planet increasingly inhospitable to man himself.

What do we mean when we say that all species have an equal right to exist? Logically this would mean that man must do nothing to decrease their numbers or to reduce the area they inhabit. Even those who, for religious reasons, do not kill, farm the land; this can cause local or even general exterminations. If it is the species which has rights, then I suspect that we like to retain some members more for our purposes than for their own.

The Ehrlichs' second reason really boils down to saying that we wish to preserve the species which give us pleasure. This pleasure may have its spiritual or even its religious components, but it acknowledges that we conserve wildlife for man's satisfaction and not for the benefit of the wild creatures themselves.

The statement about the possible economic value of wildlife has some substance. Deer and antelope are proving more efficient converters of some types of vegetation than are cattle or sheep; there may be other animals which will be profitably domesticated. Man has been very conservative in his choice of food crops, and other wild plants may be valuable sources of food. Genes of wild plants may confer valuable properties to existing crop species, so wild grasses and Andean potatoes should be preserved. Unfortunately the species of wildlife for whose preservation most effort is being 
made - the large carnivores and herbivores - would seem to have less potential except to provide pleasure and inspiration. But it is obviously good sense to try to preserve large areas of tropical forest and other habitats which contain thousands - perhaps millions - of undescribed species, whose economic potential has not been studied.

Finally, the Ehrlichs believe that unless we can maintain the diversity of the world's flora and fauna, the whole life-support system may break down. This is probably true, but the organisms which are the most important - the decomposers in the soil, insignificant parasitic insects, soil fungi and sewage organisms - are seldom the subjects of popular conservation programmes. The impoverishment of our fauna with the loss of the wolf, the bear and the wild boar has not had the effect of making farming in Britain less efficient quite the reverse.

So we must come to the conclusion that conservation is a far from simple subject. The economic and similar arguments often need to be qualified. Those based on the value of diversity are far from proven. Conservationists must avoid making statements which they know to be untrue in an attempt to obtain wider support from politicians and the general public. The most cogent reason for conservation, in my opinion, is that "man does not live by bread alone"; the general and aesthetic reasons have more validity than the economic.

Kenneth Mellanby's most recent book is Farming and Wildlife (Collins, 1981).

\section{Fighting for the conservation of tigers}

\section{Brian Bertram}

Saving the Tiger. By Guy Mountfort. Pp.123. ISBN US 0-670-61999-X; ISBN UK 0-7181-1991-6. (Viking/Michael Joseph: 1981.) \$16.95, £7.95.

THE tiger is a slim, dramatic animal, and it now has a book to match it. The numerous, large and well-printed colour plates are spectacular and superb. They do not leave a great deal of space for the authoritative text, in which the author summarizes our still scanty information on tigers, their appalling conservation plight and international attempts to prevent their extinction.

Despite the title, the tiger has not been saved, and it would be dangerous to think that it had been. Equally, it would now be much closer to extinction but for international efforts on its behalf. Guy Mountfort was both the catalyst and the power house in setting up Operation Tiger in 1972, under which the World Wildlife Fund raised nearly a million pounds for tiger conservation. He describes how the governments of India, Bangladesh and Nepal were persuaded to establish reserves for tigers, and other countries of Southeast Asia have since followed suit.

The hunting of tigers for sport is no longer a threat, thanks to national legislation in most of the countries concerned. The traffic in tiger skins for the fur trade has dwindled, thanks also to CITES, the Convention on International Trade in Endangered Species. Illegal killing of tigers is declining as local policing improves and as there is less direct contact between tigers and the local populace. The main threat nowadays is from loss of the forest habitat and the prey species on which tigers depend. Through the efforts of Guy Mountfort and others, this threat has been alleviated in many areas, and general public awareness of the plight of these wonderful animals has been raised.

What about future prospects? First, our priorities. With great difficulty and organization, large sums of money have been raised and thousands of square miles of tiger habitat protected. The total costs involved are equivalent to those needed to build a mere half-dozen miles of motorway. Which is more important? Should we have some form of conservation levy which because we human beings are so numerous would be paltry at the individual level?

Second, the status of tigers in their native reserves is relatively safe only so long as there is no breakdown of law and order in the countries concerned, and until human population pressures become irresistibly strong.

Third, although the many captive tigers in the zoos of the world are not a substitute for wild populations, they may well be a back-up. There should be tigers in the wild where they belong. But if the $350-400$ wild Siberian tigers or the 600--800 wild Sumatran tigers are exterminated through human greed or folly, there are at least 800 Siberian and 150 Sumatran tigers in captivity. I am convinced that these could be used to re-stock areas from which wild tigers had been wiped out. Certainly, it would be difficult, and would need money, time and skill, and certainly there would be failures. But there is no reason in principle why, if necessary, reintroduction should not prove possible with tigers as it has with other large cats. We only hope that it does not become necessary. Guy Mountfort has done much more than most to help prevent it.

Brian Bertram is Curator of Mammals at the Zoological Society of London.

\section{The sexes look at sex}

\section{Adrienne L. Zihlman}

The Woman That Never Evolved. By Sarah Blaffer Hrdy. Pp.242. ISBN 0-674-95540-4. (Harvard University Press: 1981.) $\$ 17.50, £ 12.25$. The Evolution of Love. By Sydney L.W. Mellen. Pp.312. ISBN hbk 0-7167-1271-7; ISBN pbk 0-71671272-5. (W.H. Freeman: 1981.) Hbk $\$ 15.95$, £8.50; pbk $\$ 8.95$.

BOOKS on the evolution of human behaviour are often more interesting for the questions raised than for the answers proposed. This is particularly true when one compares the questions posed by male and female authors about the evolution of primate sexuality. The books under review provide a classic case study in contrasting, almost mutually exclusive, viewpoints.

During the 1960s, male reconstructions of human evolution informed us that human hairlessness evolved to enhance front-to-front sex; that men's social and political clubs have sprung from the cooperative cameraderie of the male hunting groups that made our species successful millions of years ago; and that human females lost oestrus and became perpetually sexually receptive so as to keep males around to provide protection and meat from the hunt.

During the 1970s, women increasingly joined men in the game of replaying human prehistory. In place of the prevalent Manthe-Hunter scenario that put males centre stage and relegated passive, dependent females to the wings, waiting for the heroes' return, women anthropologists emphasized the important social and economic role of Woman-the-Gatherer. They also drew on sociobiological theory, which hypothesizes that the sex investing the most time and energy in raising the offspring makes the choice of mates. The central male role in the evolution of human culture and institutions was disputed by field observations on primates and on gatherer-hunters such as the !Kung San, revealing the pre-eminent involvement of females in obtaining and sharing food, choosing mates, socializing children, establishing and maintaining social networks, and using tools - in contrast with the earlier image of females as rather passive recipients of male sexual and hunting activities.

Sydney Mellen's The Evolution of Love and Sarah Hrdy's The Woman That Never Evolved provide examples of the male and female viewpoints of the $1980 \mathrm{~s}$. Both are concerned with an evolutionary overview of human nature, particularly sexual nature. Both use the theoretical framework of sociobiology, which attempts to explain contemporary human behaviour by genes that evolved millions of years ago. Mellen draws heavily on the fossil and archaeological record of the past 2-3 million years and does not dwell on non-human 